\title{
Towards a synergy between 'content' and 'process' in Dutch spatial planning: the Heuvelland case
}

\author{
Hans Mommaas · Joks Janssen
}

Received: 15 January 2007 / Accepted: 15 September 2007 / Published online: 8 February 2008

(C) Springer Science+Business Media B.V. 2008

\begin{abstract}
Spatial planning in the Netherlands is shifting from regulatory toward more developmental modes of planning. This paper explores the background of these changes and discusses current approaches to developmental planning, especially in rural areas. It combines views reflected in planning theory with the accumulated experiences of a project in the southern part of the Netherlands, called Heuvelland. The Heuvelland project is aimed at the mobilisation of market parties for spatial developments. It is an attempt to circumvent the path-dependency in which many current spatial innovation projects get caught up, owing to established institutional planning and policy arrangements. We argue that in order to stimulate innovation and create a new economic base for rural spatial developments, new economic actors and new public-private structures and networks must be mobilised. We consider how this can be done, taking into account the importance of sustainable regional development.
\end{abstract}

Keywords Development planning · Economic revitalisation $\cdot$ Rural areas · Landscape

\section{Introduction}

Dutch spatial planning has undergone some interesting changes since the late 1990s, leading to a nationwide call for a more pro-active and developmental, instead of regulatory, mode of spatial planning. According to planning professionals and academics, Dutch spatial planning must be reinvented or at least rethought if it is to meet the challenges of a post-corporatist and post-industrial society (Hajer and Zonneveld 2000; Hajer 2001). Faced with problems of effectiveness and legitimacy among a dynamic, highly educated and culturally diverse population, the new mode of spatial planning should be more receptive to

\footnotetext{
H. Mommaas

Tilburg University, Tilburg, The Netherlands

e-mail: j.t.mommaas@uvt.nl

J. Janssen $(\bowtie)$

Netherlands Institute for Spatial Research, P.O. Box 30314, GH-2500 The Hague, The Netherlands e-mail: janssen@rpb.nl
} 
emerging actors and processes in order to anticipate and accommodate future opportunities more effectively (WRR 1998). This applies not only to cities-where possibilities for a new 'cultural economy' and new leisure and consumption practices arise as alternative sources for a future urban space-but also to rural areas (Mommaas 2000a, b). After all, the primary source of rural spatiality, agriculture, is undergoing major changes.

Ongoing rationalisation processes in agriculture, a globalising agricultural market, pressure on subsidy systems, environmental problems and increasing pressure on rural space are changing the role and position of agricultural production in the maintenance of the Dutch countryside. There is talk of an emerging agriculture without soil and soil without agriculture, of the formation of a post-agrarian rural landscape and a consumption-based 'rurality'. New functions, new inhabitants and new practices are taking root in rural areas. While decreasing the power of traditional rural actors, these changes are also diversifying and complicating the rural arena, raising questions about conceptions of rural space (Frouws 1998; Marsden 1999; Mommaas 2003). Established relations between function and space are no longer self-evident. Questions about morality, experience, emotion and taste have turned the future of the countryside (once again) into an issue of public concern.

The new spatial planning would entail a diversification and mobilisation of stakeholders and a cultural re-invention of the countryside aimed at the development of a new rural economy. That need has arisen in a context in which changes are noticeable on the environmental agenda. A 'limits to growth' perspective, predominantly aimed at issues of prevention and preservation, is being exchanged for a sustainable development programme, widening the environmental agenda to include issues of sustainable social and economic growth (Hermans and Knippenberg 2006). The effect is a further increase in the complexity of the regional development agenda, with claims concerning the relations between alternative economic futures and environmental and social qualities. The challenge is not merely to prevent a zero-sum game but to create 'win-win situations' in which successful regional development goes hand in hand with an increase in environmental, spatial and social qualities.

The main question is how all these claims can be built into a planning process that stimulates new regional qualities without frustrating that very process. How can a concern for sustainable development be combined with the need not merely to plan but to develop new conceptions of rural space? In short, how can new opportunities for rural spaces be sought in a context with an increasing number of stakeholders, filling up the developmental agenda with an increasing and diversifying numbers of claims? These questions are discussed below.

The paper starts with an outline of the recent changes in spatial planning processes in the Netherlands as a backdrop to the analysis. The second section concerns the Dutch countryside and the challenges it faces, specifically the changing role of agriculture and the changing relations between city and countryside. We argue that the solution lies in synergy: simultaneously stimulating new economic activity, increasing the quality of ecology and landscape, and enhancing the quality of life in rural areas, while aiming to combine activities in innovative ways. Against the background of the changing countryside and the changes in both planning process and content we then describe how the government has been trying to create that synergy. The fourth section analyses why and how up till now most planning attempts have fallen short in creating a new economic base for rural spatial developments.

The fifth section introduces what we regard as an interesting new approach to address the issue of rural regeneration. It explores some experiences gained in the context of the Heuvelland project. In the case-study area, the southern part of the Netherlands, a network 
of market parties is actively engaged in a spatial development process to strengthen the economic, socio-cultural and ecological quality of the area. We combine these experiences with other viewpoints taken from the academic literature, thereby generating useful insights for future development planning. Finally, we reflect on both the positive and negative aspects of this new approach to planning.

\section{From regulatory planning to development plan-making}

In 1998, a report written by the Dutch Scientific Council for Governmental Policy (hereafter the WRR) called for a change in the spatial planning processes in the Netherlands (WRR 1998). Established regulatory modes of planning, based on a strong government imposing its conception of space on society, with the spatial plan as the pivotal document, were considered less and less effective. Their drawbacks were 3 -fold. First, in an open, democratic society, effective spatial planning should be based on communication and conviction rather than on principles of command and control. Second, the spatial principles on which the established hierarchical planning procedures were based were becoming obsolete, or at least questionable. In a society which was rapidly becoming more mobile, spatial functions were on the move; new conceptions of space, such as that of the networked city, the urban field or the countryside as a park, were entering the spatial discourse (Boelens 2000; Bontje 2003). Owing to this pluralisation of spatial forms, and the related decline of existing spatial hierarchies, balancing different spatial claims became ever more difficult and less self-evident. Third, the political field was changing rapidly, with new civic (NGOs) and administrative (EU) parties entering the field, resulting in a situation in which the government could no longer rely on formal-political forms of legitimisation or restrict itself to the consultation of established corporatist partners.

In addition to the above, new spatio-economic challenges required a much more proactive spatial policy for a more dynamic, competitive and globalised environment. Spatial policies should be able to motivate and facilitate, instead of simply regulate, private activities. In order to do so, they should also be able to respond much faster to changing circumstances. Because political considerations were only considered meaningful if they could lead to effective implementation of policies, the legitimation of spatial policy was directly linked to its effectiveness. Under the heading 'spatial development politics', the WRR report presented an alternative approach to the existing corporatist mode of spatial planning.

A more dynamic approach to spatial planning should, first and foremost, inform institutional arrangements, instead of the other way around. Hence, the need for more differentiated instead of generic spatial concepts, and for a more selective, strategic involvement of national government in spatial issues, leaving ample room for regional initiatives. Second, spatial planning had to be linked more directly to spatial investments. The conventional separation between conceptual planning, on the one hand, and finance and investment, on the other, should be abandoned. Future forms of public participation should no longer be focused primarily on the preparation of a conceptual plan but on concrete developments. Third, spatial development politics should no longer be restricted to established coalitions but promote an open approach to the planning process, leaving enough room for new institutional coalitions between public and private partners.

In general, the developmental approach to spatial planning proclaimed by the WRR breaks with the traditional objectives of the Dutch spatial planning system. The new approach seeks to couple the making of spatial plans with spatial investments by more 
directly stimulating private interests in the plan-making. The similarity with the 'governance' approach in the field of policy studies is clear. There, the notion of governance stands for a more open and pro-active strategy to engage public and private actors in the making and implementing of policy (Rhodes 1997). Governance turns the central government from being the dominant source of authority within a defined territory to being an activator or coordinator of negotiations between a multitude of actors over a more open, less fixed topical domain.

\section{Changing countryside}

The above-mentioned changes in spatial planning also found their way into the rural domain, especially in the 1990s. That was when a new trend emerged in Dutch rural policy: the state, civil society and market parties started seeking solutions for rural problems by carrying out region-based projects. This development must be viewed in the context of the changing functions of the countryside and, related to that, the changing balance of power between the actors and stakeholders (Marsden et al. 1993; Marsden 1999; Mommaas 2003).

\subsection{New co-producers of rural space}

In the Netherlands, for almost half a century, agricultural and countryside development have been almost synonymous. The agrarian sector successfully shaped rural policy and rural space (Frouws 1998). After the Second World War agricultural development was of primary importance, not only in order to feed the quickly growing population, but also to finance, through export profits, the recovery of the country and its industry. Post-war agricultural policy in the Netherlands was targeted at lowering the cost of agricultural products and increasing productivity through expansion, intensification and mechanisation (van den Brink 1990).

Food production and economic development were the overriding aims of this agricultural policy (Ilbery and Bowler 1998). An important facet in the achievement of these objectives was the implementation of the 'agricultural structure policy', aimed at improving the agricultural structure of underdeveloped regions. Increased concentration of capital, land and labour were paramount in this operation, resulting in planned surfaces dominated by large farms, organised along industrial lines, and located in a landscape itself characterised by a huge expansion in scale of its structures and patterns. In the 1970s, however, the productive use of the agricultural landscape through large land consolidation projects was contested. This period saw a growing political concern for nature and ecology. In line with an increase in auto-mobility and expanding housing patterns, more and more city-dwellers started to appreciate the socio-cultural, historical and ecological characteristics of the countryside.

Because of these suburbanisation processes, the traditional agrarian function of the Dutch countryside faced increasing competition from new functions such as housing, nature and recreation. More and more farmers but also others formerly engaged in rural activities found jobs in cities, and increasingly more people settled in the countryside. With this change of functions and the arrival of new stakeholders, the power balance shifted. From the late 1970s on, this resulted in a fierce battle between nature conservationists and farmers. Both parties claimed their part of the rural environment. The exclusive domain of closed economic-political networks in which agrarian actors and their representatives 
dominated came under fire. Non-agrarian actors could no longer effectively be excluded from the rural scene. Spatial planning became an important tool for government agencies to resolve the problems between the different functions.

In the years thereafter agriculture could not play its role as the undisputed supporter of rural areas any longer. New organisational principles were needed in order to diversify and revitalise the rural economy and at the same time strengthen the greatly appreciated ecological and socio-cultural qualities of rural space. In addition, the need for a new rural policy became acute. The role of the national government, i.e. the Ministry of Agriculture, Nature Management and Fisheries, as a prime mover behind the reconstruction of rural areas had collapsed; agricultural stakeholders lost ground and new co-producers of rural space were needed.

\subsection{Rural development planning}

In the 1980s and 1990s, major reforms in public administration took place, decentralising and delegating powers for the physical and financial co-ordination of rural policy programmes issued by the national government (Padt 2007). It was believed that decisions about the various rural roles or functions should be taken at the regional level. As a result the regional administrative tier was revived. Provinces came to the fore and claimed a prominent role in regionally oriented rural development, eagerly using the new ideas on development planning (IPO 2005). The proclamation of a new director's role for provincial governments can be seen as an expression of their renewed self-confidence.

Recent national government policy primarily holds the provinces responsible for realising the (governmental) targets in the region. The provinces have to do this in collaboration with municipalities, district water boards, local residents and civic organisations. For that reason, the various national government budgets and subsidy schemes for area-oriented policy, land development, soil sanitation, etc. are integrated into one flow of money: the ILG Investment Fund for Rural Areas. For the fund to become a financing scheme for the provinces, the decision-making about the destination of the money was decentralised.

The provinces could then redistribute the funds for regional and local projects. The policy gave them more authority and regulatory powers not only to draw up (strategic) spatial plans but also to translate them into operational projects that could be implemented. Furthermore, new legislation is on its way which will strengthen the provincial tier of government. For instance, the new spatial planning act (2007) will give provinces the power to draw up land use plans for specific territories; these will have the same legal status as the municipal land use plans. There is also a substantial role for the provinces in the Netherlands' implementation of European Rural Policy in the period between 2007 and 2013, laid down in the Rural Development Plan.

Against this background, the key question is how the provinces are actually coping with the challenges facing the countryside and with the new planning and policy tools at their disposal. How do they make use of their new 'capacity to act'? Do their actions stimulate development planning, giving centre stage to economic opportunities in the area and the implementation of plans? The answer is two-sided. On the one hand provinces have developed more pro-active strategies. For instance, they are more deeply involved in the implementation of land policy, an activity previously reserved for municipalities (JanssenJansen 2004). Provinces have a stake in the land market, giving them means to safeguard public interests. And nowadays, it is common practice for provinces to make risk-bearing investments in land. 
A well-known example is the project called Space for Space (Ruimte-voor-Ruimte) in the province of North-Brabant. The project is part of the reconstruction of the sandy areas, which entails a rationalisation of livestock farming and reduction of environmental impact. The objective of Space for Space is to remove livestock barns (Driessen 2005). This operation is financed by developing new residential areas after decontamination. Space for Space was set up as a public-private partnership, involving the Province of North-Brabant, the Bank Nederlandse Gemeenten, and two construction concerns, Heijmans/IBC and Grontmij.

Although the project has been successful in some respects, both politicians and planners have criticised it for two reasons. First, according to some, the project is blurring the boundaries between public policy-making and investing as well as between public and private parties (Louw et al. 2003). Combining two responsibilities (public control and public development) could very well lead to conflicts of interest. After all, when the government is not able to carry out the core tasks of oversight, it will lose its legitimacy as a democratic institution.

Second, Space for Space deals with expansion and growth strategies, not with reconstruction, redistribution or conversion. Investment in 'green' structures is channelled through housing schemes which bring in the necessary money. The government relies on these new financing mechanisms ('red for green'), in the hope that the favourable returns from real estate (red) development will provide opportunities for investing in green qualities. Current experiences with these types of projects, however, demonstrate that the green qualities are mostly only realised within the housing schemes themselves (MNP 2005). Examples of larger, regional green spaces, financed by red developments and situated outside the existing boundaries of towns and villages, are rare. In order to realise these, regional land value capture and redistribution mechanisms are needed in addition to financial agreements.

Although the provinces are beginning to think and act in terms of public entrepreneurship, it is by no means certain that the provinces should always take the lead, determining the rules of the game, the actors involved, and the modes of alignment. Instead, the provinces could play different roles (director, partner, facilitator, controller), depending on the situation and the stakeholders involved (Weerd-Van de Poll and Van den Brink 2005; see also IPO 2006). One of the reasons, we argue, to play a facilitating and supporting role in rural development planning rather than a risk-bearing one is that the provincial government lacks the necessary knowledge and experience in active land development. Besides, the government is still accepted as the first and only port of call for a solution in regional development. Therefore, the role of the private sector is not properly recognised in the plan-making processes. Because the increasing influence of private players and corporate actors is not acknowledged, there is a lack of commitment, investment capacity and implementation perspective in the course of the planning process (Kreukels 2004).

\section{Drawbacks of development planning}

The latest spatial policy approach for rural areas is area-based (Boonstra and Frouws 2005). By taking a region-instead of sector-based approach, the area-based policy can overcome the compartmentalisation of the policies of the different government agencies involved in countryside planning. It pursues a coordinated policy implementation by setting up partnerships between government bodies and public and private stakeholders. The emphasis is on improving the planning process while implementing plans and projects. 


\subsection{Hampering innovations}

Verwest et al. (2005) and Dammers et al. (2004) argue that the groundbreaking innovations envisioned for current area-based projects fail to occur. They mention three characteristics that hamper the necessary innovations. The first is the attempt to integrate the different functions and policy fields involved in area-based projects. This often results in container plans: compromises in which too many things are interwoven. Although these plans lead to consensus, they do not stimulate any steering of development and physical innovation. While integration suggests an equal contribution of the partners involved in policy-making, in practice, the more powerful stakeholders largely determine the outcome of the planning process. Besides, integration can also become a goal in itself, obscuring the focus on resolving actual problems.

The second drawback, related to the first, is the supposedly open character of the planning process. Regional authorities, such as the provinces, often use the area-based development approach as a tool to achieve their own goals along with those of important partners such as agricultural organisations and nature conservation boards. The authorities do not perceive it as a means of mobilising other actors to define their contributions to a project by making the necessary economic investments. Many representatives of government agencies and NGOs also stick to old patterns of decision-making, thereby hindering the mobilisation of new actors. Although this behaviour is understandable - for decades Dutch planning was solely a hierarchal government-led activity-its negative consequences are far-reaching. Most regional plans lack a real development-based attitude and remain spatially oriented. As a result, projects are not accommodated sufficiently and chances are being missed to mobilise new actors, resources and discourses.

Third, in contrast to its objectives, integrative area-based planning has not proven to be focused on implementation. Evaluations of integrated area-based policy demonstrate that much time and effort is spent on plan-making (Boonstra 2004; RLG 2004; Bakker 2006; Rooy et al. 2006). Reaching consensus on the plan beforehand, it is believed, can prevent delays and obstacles later on during the planning process. The power of this approach lies in generating commitment and formulating visions. However, it is not enough to encourage commitment and a sense of responsibility among the stakeholders; it takes more to carry through the innovation and implementation of (regional) plans. Sometimes integrative area-based planning only leads to defensive and sluggish behaviour because the government steering is focused on maximal coordination.

Although new ways are being sought to fill the legitimacy gap in area-based policies, they are still hampered by a strong 'inside-out' approach. The development actors (mostly market parties) are only allowed to join in after the plans have been established. Their arrival mostly follows the stages of cooperation and negotiation between government agencies, civil society and semi-public institutions (Boelens and Mommaas 2005). The resulting partnerships between governmental bodies and sectoral or civic stakeholders are laid down in covenants that not only take current legislation for granted, but also limit the room for private entrepreneurship. Many area-based plans thus end up as promising futures in the galleries of 'unbuilt Holland', however integrative, deliberative or enthusiastic the planning process underlying them. Despite their dynamism and inspiration, they have failed to resolve the gap between content and process, plan and development. In the exceptional event that the plans are successful, the gap is likely to be filled by public institutions or larger institutional investors who take the lead in the development process. 


\subsection{Towards a new agenda}

Since the publication of the WRR report, substantial steps have been taken to shift from a plan-led planning system towards a development-led one. The national government seeks to tie in with socio-cultural and economic trends rather than fighting them, thereby moving from 'imposing restrictions' to 'promoting developments' (Vink and Van den Burg 2006). However, at the regional level provinces have a hard time acting as innovative development agencies. Despite their newly gained status, their performance impedes the involvement of market parties who can invest economically in the countryside (Bakker 2006; Rooy et al. 2006). Following Dammers et al. (2004) and Boelens et al. (2006) we therefore argue that an important and unresolved problem remains in (rural) development planning. The traditional separation between the conceptualisation of a spatial plan and the actual development process still exists. New approaches are needed in order to overcome this separation. These must go beyond the newly promoted developmental planning and current partnerships between governmental bodies and sector or civic stakeholders. The analysis of the Heuvelland case, presented below, is an attempt to better understand the chances and limitations of actively engaging market parties and stimulating businesslike styles in rural regeneration.

\section{The Heuvelland case}

\subsection{Searching for new economic stimulus}

The Heuvelland region is one of the oldest touristic regions in the Netherlands. The landscape is characterised by rolling hills, hilly forests, brooks, sunken lanes and meandering rivers. This hilly landscape is unique in the Netherlands. Because of its appeal to citydwellers, Heuvelland was already connected in the 19th century by express trains to the densely populated Randstad area. The importance of the tourism sector is exemplified by the town of Valkenburg, where almost $70 \%$ of the jobs are related to tourism. Together with agriculture, tourism is an important co-producer of the hilly landscape. However, both tourism and agriculture are under increasing pressure; owing to international market forces, both are experiencing a profit squeeze. In the case of tourism, low-cost airlines are enabling people to take cheaper holiday trips outside the Netherlands. In the case of agriculture, the ongoing industrialisation of food production is lowering the costs per unit. It was feared that, if left to their own line of development, both tourism and agriculture would gradually become marginalised, no longer able to act as co-producers of the landscape. Hotels unable to keep up with the competition were already being sold to property developers, who were turning them into apartment buildings.

How could the economy of the hilly landscape be strengthened to accommodate the mutual dependency between tourism, on the one hand, and the cultural and ecological qualities of the landscape, on the other? Furthermore, how could an innovative strategy be designed to accommodate the impending economic developments? For instance, a new service economy is taking hold in the hilly landscape. A large share of the region's output no longer comes from the vertical value chains of a global agricultural production system but from the horizontal value chains of a regional urban-rural service economy. This segment links small-scale agricultural production to tourism and recreation, health care, shopping, hotel and catering, nature maintenance, and heritage culture. 


\subsection{The future of tourism in a hilly landscape}

Several governmental attempts to create a new economic base for the hilly country of South Limburg in the period before 2004 have proved unsuccessful. Thus, for 2 years an alternative approach has been explored. Not the presumed qualities of nature and culture are the primary focus of attention here, but the necessity to mobilise regionally bounded or embedded businesses and other market parties - actors that are able economically to maintain and further develop those qualities (Zka et al. 2005). The project involved an attempt to link content and process in a more direct and productive way. The starting point for the project was not so much a spatial planning issue but concern about the economic future of the region, especially regarding tourism.

In early 2004, the regional investment and development agency (LIOF) ventilated concerns about the future of regional tourism. Together with the provincial government, who underlined the need for more dynamism in the tourism sector, and Tilburg University (Department of Leisure Studies), LIOF set up the project 'Heerlijkheid Heuvelland'. In order to make room for private entrepreneurs to develop their own ideas on the economic regeneration of Heuvelland it was clear that the provincial government would not actively participate in the planning process.

An extensive analysis of the composition of the tourist value chain, both in general and specific to the region, was carried out; this activity was supported by Zka Consultancy, an advisory bureau specialised in leisure and tourism. The conclusion was that the position of the tourism sector was not future-proof. The financial and investment structure within the sector was dominated by a short-term orientation and was primarily focussed on the transport and accommodation elements of the sector itself. If investment money remained, this was predominantly invested in the narrowly defined tourist production column.

The sector is heavily dependent on environmental qualities, the raison d'etre of tourism in the region. Yet the tourism sector itself does not invest in these qualities, leaving that to the public sector (perhaps partly using tourist tax income), other institutions more directly concerned with nature and culture (recreational facilities, museums, etc.), or the tourists themselves. Hence, for several reasons, a more horizontal strategy was needed, aimed more directly at maintaining cultural and natural qualities, stimulating regional 'traffic', and through that also enhancing the preconditions for ongoing tourist activities. Regional cultural and natural qualities had to form the basis for new impulses for economic revitalisation. Making use of an Intereg IIIc subsidy (the TouriSME) programme, and with the help of Urban Unlimited, an urban planning bureau, the project could also draw the spatial dimension into its programme.

\subsection{Greetings from...the entire world}

The project started with an inventory of the core values of the region, both natural (the landscape and its various ingredients) and cultural (monuments, cultural activities, the types of social relations, occupation patterns). The inventory was based on interviews with key players in the region and on a secondary analysis of existing data, especially with regard to regional business activities and tourist typologies. The data were expressed in maps, enabling a topographical overview of a variety of service structures (sports, wellness, health care, gardening, gastronomy, orchards and vineyards). The design element played a key role; the region was presented to the entrepreneurs in an attractive way, not through words, but through images and references. This was crucial in triggering the imagination and searching for new prospects. Because regional cultural and natural qualities in 
Heuvelland were not presented as external qualities in need of preservation and protection, but as something to be developed and as a possible investment opportunity, the parties quickly incorporated these qualities as a positive force.

Next, a search was organised for European points of reference. The references had to concern regions in which, on the basis of comparable regional qualities, horizontal clusters of economic activities had been developed. On the one hand, these activities had to act as co-producers of regional natural and cultural qualities. On the other hand, they had to stimulate tourist activities, delivering a surplus value to the tourist value chain. The references chosen included the Burgundy region (alliances related to wine production), Baden-Baden (alliances related to health and wellness), Poitiers (media and technology), Billund (product branding, in this case Lego) and Nice (science and technology). The references were brought together in a booklet titled Greetings from ... the entire world (Urban Unlimited et al. 2004). The references were investigated in order to determine how regional value chains were interwoven both with natural and cultural qualities and with tourism.

The material collected was summarised in the form of a regional matrix, expressing the red and green core qualities of the region (monasteries, mills, farmhouses, hilly roads, orchards, hills and valleys) and the potential new markets. Finally, five themes were selected: Healing Hills (linking the infrastructure of convents and woods to new health and care possibilities); Rich Tastes (linking, e.g., farms and orchards to regional food); Lush Gardens (combinations of the infrastructure of castles and gardens with new lifestyle markets); Linked Fields (relating churches, chapels, and the small-scale landscape to possible multimedia activities); and Elementary Heritage (the landscape of watermills and valleys linked to new energy $R \& D$ ).

These themes, and the related visual materials (maps and images), were presented at round-table meetings with entrepreneurs and investors active in the region. The inclusion of market parties resulted from an active search, both regionally and nationally, for entrepreneurs who were considered interesting for the project because they had already proved to be innovative and willing to invest. The sessions were meant to test the potential perspectives and to attract horizontal investments capable of supporting the natural and cultural qualities. These qualities were considered not merely as nice scenic ingredients but as crucial elements of projected value chains.

\subsection{Developing product market combinations}

Both medium-sized and larger enterprises (see below) were represented at the round-table meetings. In general, the response was enthusiastic. Especially the ways in which areabased value chains were linked to one another, to the cultural and natural qualities present in the region, and to area-based agricultural production, the gastronomic economy, wellness and healthcare, technology and innovation gave new impetus to the search for additional investments. Based on explicit investment propositions, five development opportunities were finally identified. A group of interested entrepreneurs was assembled for each of these opportunities.

The five themes were given the following profiles. 'Healing Hills' was depicted as a combination of hospitals and hotels aimed at the development of a new health-care infrastructure enabling surgical patients to recuperate in regional hotels. 'Rich Tastes' was designed as a combination of regional food producers and a regional distribution company, aimed at scaling up the regional food chain, linking it more closely to the urban-rural tourist market, the regional chain of quality restaurants, gastronomy courses, etc. 'Wellness in Luxury' was aimed at inducing insurance companies to organise preventive care trajectories, 
in combination with health resort stays, therapeutic baths and training courses. 'Glorious Life' was a new formula for senior housing in monumental buildings, in combination with health-care guarantees. Finally, an opportunity presented itself to cover the whole area with a wireless broadband connection, enabling wireless availability of health-care and tourist information, together with real-time gaming; hence the name 'Linked Fields'.

At the moment, the five propositions are being worked out by five groups of entrepreneurs. Orbis, a medical service centre, took the lead in developing an investment strategy for 'Healing Hills'. Together with the hotel group Château St. Gerlach a 7-day vitality and healing arrangement for knee and hip operations was elaborated. Based on the Joint Care principle (in which a patient is accompanied by a coach (friend, family member or partner), patients can recuperate from their operation in a healing environment. For Orbis it was an attempt to attract a new public and enter a new market; for St. Gerlach it offered new chances to attract customers during the off-peak season and the quiet midweek. The 'Rich Tastes' theme centres around a permanent regional food market in the newly developed Mosae Forum themed shopping centre in Maastricht. The project is being elaborated by the Van Melik Food Group, a region-bound food business specialized in quality products. The idea behind the marketplace is to offer a distribution channel for small-scale purveyors of regional food products. By concentrating turnover in a place which is visited by many tourists, a larger market potential can be reached.

In all cases companies were entering new markets where they had no presence before. The further they moved away from known quantities, i.e. the existing product and the existing market, the greater the element of risk became for the entrepreneurs. In order to extend existing markets and products the selected entrepreneurs had to be willing and able to take risks and invest. The leading firms were flanked by other entrepreneurs, who were interested in developing new product market combinations (PCMs) but were not able to take the initiative or bear the risk. In the case of 'Rich Tastes', for instance, the Van Melik company developed an alliance with local retailers, farms, orchards and restaurants.

The newly developed PCMs had to be interesting to the participating companies in terms of economic growth and opportunities. But they also had to appeal to the wider environment in terms of strengthening regional cultural and/or natural characteristics. An illustration is the 'Glorious Life' theme. There, an alliance between a custom project developer, home-care services and cultural heritage interests-entailing a plan to house elderly people and empty nesters in restored convents and castles with new landscaping-penetrated a new market for the involved companies. At the same time, the alliance created a new economic base and programme for highly valued but threatened cultural heritage objects.

\section{Reflection}

Although it remains unclear how the project will develop, some promising characteristics can be discerned, deviating from the above-mentioned drawbacks in current development planning. First, the project was actor-oriented instead of plan-oriented. It focused on entrepreneurs who wanted to think and act strategically. The first attempts in the planning process were thus directed at discovering their motives and arguments. The group of selected entrepreneurs was kept small in order to reduce complexity in the field of action. Following Kohler-Koch and Eising (1999), it was assumed that governance should not be aimed at mobilising as many actors as possible within a certain region. Rather, only those who have a certain stake in the problem at hand and are willing to solve it should be recruited. 
Because of the urge to become involved as investing parties themselves, entrepreneurs only interested in short-term gains left the tables at an early stage.

Second, instead of taking the lead provincial government has kept a low profile. It has not simply told the market parties, through its regional spatial plan, what they can and cannot do. Instead, it has given them the space to develop and express ideas about their own environment in order to create a more open, integrated approach to possible value chains. The regional and local political stakeholders were informed about the project, and those who were involved clearly supported the idea. Semi-public interest organisations were not invited to participate. They were thought to strengthen existing sectoral cleavages, thus hindering an integrated, horizontal approach to new investment opportunities. An exception was made for 'Het Limburgs Landschap', an organisation concerned with the preservation of the small-scale landscape of Limburg. Hence, the project was primarily based on groups of entrepreneurs, and did not depend on abstract appeals for collaboration or a pre-defined government plan. The project relied on self-defined 'windows of opportunity', stimulated by an informed perspective on the region.

Third, a separate structure was created, alongside the existing government institutions, for co-producing activities. The purpose was to enable the market parties to strengthen their regional embeddedness, identity and inter-activity. In terms of regime theory, these groups of entrepreneurs can be seen as potentially organising a development-based coalition or regime, creating a collaborative space for new opportunities (Stone 1993; Stoker and Mossberger 1994; Stoker 1995; Mossberger and Stoker 2001). Within this separate space the regional investment and development agency (LIOF) acted as the central coordinating party of the project. Because LIOF was neither a purely public nor a purely private body it was able to connect the language of 'serious' banking and investment with the language of public policy making. Furthermore, the entrepreneurs involved could not address LIOF as a regulating nor a subsidising body. Hence, they were forced to interact as professional entrepreneurs 'amongst each other'.

In the beginning, this regime was able to circumvent existing institutional and spatial arrangements, creating a new space for action and enabling the generation of further prospects and investments. The conventional gap between conceptual planning and development processes was narrowed substantially. A precondition for bridging the gap, of course, is that the government allows for and facilitates the coming into being of parallel structures. In such structures, corporate organisations are able to exercise their social responsibility as co-producers of space. An institutionally secured regional value map should prevent this parallel structure from weakening instead of strengthening existing spatial qualities.

Fourth, and related to the above, there was no desire for new formal structures. Preliminary time and energy was not spent on endless discussions about the shape of the cooperation or about a distribution of tasks and responsibilities; the work itself began straight away. The fact that the cooperation between entrepreneurs was not (legally) imposed from above but had a voluntary basis in the initiative of the parties themselves contributed to its effectiveness. It meant that participating partners were motivated to make a success of the proposed new product market combinations. The entrepreneurs are not bound to anything, at least not formally. However, informal ties can be as effective as formal ones. In any case, voluntariness and sound pragmatism went hand in hand. The fact that the entrepreneurs treated each other as partners rather than competitors was rather innovative.

The greatest risk of the Heuvelland project is that it makes democratic control more difficult. After all, a network of entrepreneurs cannot be called to account on anything. In the beginning the process was largely hidden from the critical eyes of the outside world; there were no participants from formal administrative bodies. Consequently, one could argue that Heuvelland's democratic or public legitimacy is rather underdeveloped. Since 
public legitimacy plays a key role in the development approach as advocated by the WRR and others, this issue needs some attention. One way to improve accountability is to make the Heuvelland network more open and public. The steering group that currently coordinates the project (consisting of representatives of the project groups, representatives from the provincial government, the regional investment and development agency, and the field of research and consultancy) could be assigned the task of forging links with public governmental organisations and civic organisations.

Furthermore, numerous practical problems and questions are involved in combining private entrepreneurship and governmental decision-making procedures. For instance, how do the proposed product market combinations relate to the legally binding regional spatial plan? In the near future, therefore, time has to be devoted to bringing the projects into line with formal planning documents concerning long-term goals, priorities and money. However, this should be done while avoiding the real risk that the informal entrepreneurial cooperation will then lose its flexibility and innovative potential. In order to avoid these negative side-effects, the steering group is developing a knowledge infrastructure that might be able to address the many economic, cultural, judicial, spatial and planning questions. Besides, a regional investment fund has been founded, strengthening the relations between the projects. It also links the projects to the original aim of strengthening the core qualities of the region.

\section{Further research}

The Heuvelland case suggests only one possible way of more effectively linking regional spatial qualities ('content') with future-oriented investments ('process') in cases with a more complicated coalition whereby different actors are involved in the development process. Different regional or project conditions and different spatial scales probably require different developmental strategies. For this reason, the Heuvelland case cannot be understood as a simple model that could easily be applied to other places and situations. Each specific case must devise its own innovative development path, depending on the type of parties involved, the starting situation, and the specific regional qualities to be addressed. Nevertheless, research of this kind may help open the eyes of the politicians, planners and administrators involved in regional development projects. They might then be able to find new economic actors who can act as co-producers in the redevelopment of an existing landscape. And they might find ways to link new economic actors involved in the development of new economic activities for the redevelopment of an existing landscape. Furthermore, it may help them to recognise the possibilities and the limitations of a more market-driven regional development approach.

Acknowledgements We would like to thank the editors of this journal and three anonymous reviewers for their useful comments and suggestions.

\section{References}

Bakker, R. (2006). Ontwikkel kracht! Eindrapport van de adviescommissie gebiedsontwikkeling. Amersfoort: Lysias Consulting Group B.V.

Boelens, L. (2000). Nederland netwerkenland. Een inventarisatie van de nieuwe planologie en stedebouw. Rotterdam: Nai Uitgevers. 
Boelens, L., \& Mommaas, H. (2005). Voorbij het plan: de actorbenadering. In N. Aarts, R. During, \& P. van der Jagt (Eds.), Te koop en andere ideeën voor de inrichting van Nederland (pp. 153-160). Wageningen: Alterra.

Boelens, L., Spit, T., Wissink, B., \& De Jong, B. (2006), Planning zonder overheid. Een toekomst voor planning. Rotterdam: 010 Publishers.

Bontje, M. (2003). A planner's paradise lost? Past, present and future of Dutch National Urbanization Policy. European Urban and Regional Studies, 10, 135-151.

Boonstra, F. (2004). Laveren tussen regio's en regels. Assen: Van Gorcum.

Boonstra, W., \& Frouws, J. (2005). Conflicts about water: A case study of contest and power in Dutch rural policy. Journal of Rural Studies, 21, 297-312.

van den Brink, A. (1990). Structuur in beweging: het landbouwstructuurbeleid in Nederland 1945-1985. Wageningen: Wageningse Economische Studies.

Dammers, E., Verwest, F., Staffhorst, B., \& Verschoor, W. (2004). Ontwikkelingsplanologie. Lessen uit en voor de praktijk. Rotterdam: NAi Uitgevers.

Driessen, P. P. J. (2005). Restructuring the Dutch countryside: Limits of a governance strategy. Planning Practice and Research, 20(1), 69-77.

Frouws, J. (1998). The contested redefinition of the countryside. An analysis of rural discourses in The Netherlands. Sociologia Ruralis, 38(1), 54-68.

Hajer, M. (2001). The need to zoom out: Understanding planning processes in a post-corporatist society. In A. Madanipour, A. Hul, \& P. Healey (Eds.), The governance of place. Space and planning processes (pp. 178-203). Ashgate: Burlington.

Hajer, M., \& Zonneveld, W. (2000). Spatial planning in the network society. Rethinking the principles of planning in the Netherlands. European Planning Studies, 8(3), 337-356.

Hermans, F., \& Knippenberg, L. (2006). A principle-based approach for the evaluation of sustainable development. Journal of Environmental Assessment Policy and Management, 8(3), 299-319.

Ilbery, B., Bowler, I. (1998). The geography of rural change. Harlow: Longman.

IPO - Interprovinciaal Overleg (2005). De provincie als publieke ontwikkelaar. Rol en ambitie van de provincies in het landelijk gebied. Den Haag: Interprovinciaal Overleg.

IPO - Interprovinciaal Overleg (2006). Het provinciale initiatief. De provincie als motor van regionale ontwikkeling. Den Haag: Interprovinciaal Overleg.

Janssen-Jansen, L. B. (2004). Regio's uitgedaagd, 'Growth Management' ter inspiratie voor nieuwe paden van pro-actieve ruimtelijke planning. Assen: Van Gorcum.

Kohler-Koch, B., \& Eising, E. (Eds.) (1999). The transformation of governance in the European union. London: Routledge.

Kreukels, T. (2004). Regionale regie - Wie stuurt de agenda?. In E. Pasveer \& P. P. Witsen (Eds.), BVR. Ruimte en regie (pp. 42-55). Bussum: Thoth.

Louw, E., van der Krabben, E., \& Priemus, H. (2003). Spatial development policy: changing roles for local and regional authorities in the Netherlands. Land use Policy, 20, 357-366.

Marsden, T. (1999). Rural futures: The consumption countryside and its regulation. Sociologia Ruralis, 39 , 501-520.

Marsden, T., Murdoch, J., Lowe, P., Munton, R., \& Flynn, A. (1993). Constructing the countryside. London: UCL Press Limited.

MNP - Milieu- en Natuurplanbureau (2005). Natuurbalans 2005 [Nature balance]. Bilthoven: Milieu en Natuurplanbureau.

Mommaas, H. (2000a). De verstrooide stad als cultuurpolitieke uitdaging. In F. Hendriks \& P. Tops (Eds.), Stad in Spagaat. Institutionele innovatie in het stadsbestuur (pp. 53-76). Assen: Van Gorcum.

Mommaas, H. (2000b). De vrijetijdsindustrie in stad en land. Den Haag: Sdu Uitgevers.

Mommaas, H. (2003). Op zoek naar Arcadië. Over de sociaal-culturele dimensie van de groene ruimte. In N. J. Beun (Ed.), Sociaal-culturele aspecten van groene ruimte en voeding (pp. 47-80). Den Haag: Innovatienetwerk Groene Ruimte en Agrocluster.

Mossberger, K., \& Stoker, G. (2001). The evolution of urban regime theory. The challenge of conceptualisation. Urban Affairs Review, 36(6), 810-835.

Padt, F. (2007). Green planning. An institutional analysis of regional environmental planning in the Netherlands. Delft: Eburon.

RLG - Raad Landelijk Gebied [Council for Rural Areas] (2004). Platteland aan het stuur. Advies over vernieuwende vormen van bestuur voor het landelijk gebied. Amersfoort: Raad Landelijk Gebied.

Rhodes, R. (1997). Understanding governance. Buckingham: Open University Press.

van Rooy, P. T. J. C., Van Luin, A. B., \& Dil, E. (2006). NederLandBovenWater. Praktijkboek Gebiedsontwikkeling. Gouda: Uitgave Habiforum. 
Stoker, G. (1995). Regime theory and urban politics. In D. Judge, G. Stoker, \& H. Wolman (Eds.), Theories of urban politics (pp. 54-71). London: Sage.

Stoker, G., \& Mossberger, K. (1994). Urban regime theory in comparative perspective. Environment and Planning C, 12, 195-212.

Stone, C. (1993). Urban regimes and the capacity to govern: A political economy approach. Journal of Urban Affairs, 15, 1-28.

Urban Unlimited (2004). Greetings from...the entire world (Rotterdam: [http://www.urbanunlimited.nl]).

Verwest, F., Dammers, E., \& Staffhorst, B. (2005). Ontwikkelingsplanologie: voorbij het poldermodel. $R u$ imte in Debat, 2, 2-9.

Vink, B., \& van den Burg, A. (2006). New Dutch spatial planning policy creates space for development. DISP, 164(1), 41-49.

De Weerd-Van de Poll, H., \& Van den Brink, A. (2005). Provincies op weg naar ontwikkelend grondbeleid. Landwerk, 6, 38-41.

WRR - Wetenschappelijke Raad voor het Regeringsbeleid (1998). Ruimtelijke ontwikkelingspolitiek. Den Haag: SdU Uitgevers.

Zka, Urban Unlimited, \& Universiteit van Tilburg (2005). Heerlijkheid Heuvelland; nieuwe markten en allianties voor toerisme in het Heuvelland. Maastricht: Liof. 